\title{
Weaponizing nature: The geopolitical ecology of the US Navy's biofuel program
}

\section{Abstract}

The United States military is treating climate change as a crucial factor in its preparation for

future conflicts. This concern manifests not only in strategic planning and forward-looking

documents, but also in building infrastructural capacity and material provision. Yet, the impetus

to 'green' the military goes beyond the deployment of existing technologies. We examine several

facets of the military's role as an environmental actor, particularly through its promotion of the

US Navy's 'Great Green Fleet' (GGF), which actively supports the development of advanced

biofuels by subsidizing their development and facilitating wider marketization. The GGF

promises to reduce military reliance on conventional fossil fuels and reconfigure its energy

sourcing, thus reducing dependence on imported hydrocarbons; this is with an eye towards

ultimately severing the logistical relationship between existing energy infrastructures and the

spaces of military intervention. Taking an integrated lens of political ecology and geopolitics -

'geopolitical ecology' - we seek to provide an understanding of the production of weaponized

nature. We demonstrate that the US military's discursive use of climate change to justify the 
THIS IS A PRE-COPY EDITED DRAFT OF ACCEPTED ARTICLE IN POLITICAL GEOGRAPHY 2017

provision of new military hardware and advanced biofuels promotes a vision of resource conflicts to support the development of technologies to overcome the constraints to delivery of

fuel to emergent front lines. We argue that while this may appear to be militarized greenwashing,

it signals a shift in the logics and practices of fuel sourcing driven by a dystopian vision of climate change, which the US military played a significant role in creating.

Keywords: Geopolitical ecology; Biofuels; US Navy; Markets; Territory

Running headline: Weaponizing nature

This research was supported in part by FP7 Marie Curie Initial Training Network, ENTITLE project (number: 289374), European Network for Political Ecology. 
'The impacts of climate change may increase the frequency, scale, and complexity of future missions, including defense support to civil authorities, while at the same time undermining the capacity of our domestic installations to support training activities. Our actions to increase ... renewable energy sources will increase the resiliency of our installations and help mitigate their effects.'

(US Department of Defense Quadrennial Defense Review: Hegel, 2014)

'The Navy is open for business.'

(Vice Admiral Dennis McGinn, US Navy: in Lane, 2013)

\section{INTRODUCTION}

January 2012 was momentous for the United States Navy and for a number of seemingly unrelated actors, from cattle ranchers and chicken farmers to climate scientists. At the 2012 Rim of the Pacific Exercises, the world's largest naval war game, US Navy Secretary Ray Mabus demonstrated the United States' newest and most advanced naval strike force, the 'Great Green Fleet' (GGF). For Mabus, this tactical fleet, including both ships and aircraft, validated what the Navy described as its commitment to fighting global climate change through energy-saving technologies and adoption of advanced biofuels made from a variety of non-food feedstocks, including algae, crop residues, vegetable oils and processed beef and chicken animal fats (Hess \& Joyce, 2016). Yet while Mabus trumpeted future maritime superiority through reduced dependence on conventional hydrocarbons, the stakes are potentially much higher: to radically reconfigure the US military's long-standing and complicated logistical relationships with fossilfuel infrastructures in light of emerging geopolitical entanglements influenced by climate 
change. This goal has become increasingly important given the US military's projections of more frequent and dispersed conflicts and the role of the military in responding to humanitarian disasters brought on by climate change. ${ }^{1}$ The Navy is treating climate change as a crucial factor in its preparations for domestic and overseas operations. This moves beyond strategic planning and forward-looking documents, to building infrastructure capacity and changing material provision, including US unconventional fuel refining and distribution capacity. With a few exceptions, however, the political meaning and socio-ecological implications of the military's increased attention to climate change remain largely unexamined (Chambers \& Yativ, 2011; Gilbert, 2012).

The aim of this article is to examine the US Navy's understanding of climate change in justifying its development of the GGF and reimagining the US military's role in a warming world. We do so by advancing 'geopolitical ecology' as a conceptual framework that combines the strengths of political ecology with those of geopolitics in order to account for, and gain a deeper understanding of, the role of large geopolitical institutions, like the US military, in environmental change. We illustrate the material effects of the US military's pessimistic projection of a warming world and how it uses this to justify not only the adoption of new technologies, but a potential transformation in how it fights wars. We demonstrate that the Navy's move towards biofuels is not just a simple case of 'greenwashing' or a contemporary twist on domestic energy security, but a strategic mobilization to transform energy spatialities while projecting military dominance in emerging spaces of conflict perceived to be exacerbated by climate change (Gilbert, 2012; Buxton \& Hayes, 2015).

Geopolitical ecology can be thought of in reference to Blakie and Brookfield's (1987, p. 13), classic definition of political ecology as ' ... combining the concerns of ecology with a broadly 
defined political economy.' We expand on this definition of political ecology, placing geopolitics alongside political economy, as it is critical not to lose sight of specifically capitalist political economics in (and often for) which military force is utilized (Lenin, 1911; Harvey, 2003;

Mitchell, 2013). In other words, by adding the 'geo' prefix we seek to find synergies between political ecologists' careful attention to multi-scale environmental politics and the discursivematerial co-constitution of global institutional geopolitics. We make no great claims to novelty in this regard - the impetus to create this kind of framework is well established, for example, in the work of Juanita Sundberg (2011), Timothy Mitchell (2013), Chaturvedi \& Doyle (2015), Simon Dalby (2014) and, to some extent, the 'world ecology' literature (e.g. Moore, 2015). However, we feel that an explicit encounter between critical geopolitics and political ecology is timely (Benjaminsen et al., 2017), particularly if we are to understand the larger institutional processes at work to discursively and materially produce global natures.

The US Navy's adoption of drop-in biofuels is just one part of a host of climate change mitigation and adaptation strategies to 'weaponize' material aspects of nature and adopt discourse that frames nature both as a military asset and as a set of problems to be overcome through military means (Mitchell, 2003; Kosek, 2010). Nature is weaponized when it is 'used by armed actors to do harm' (Koopman, 2016, p. 530). While the Navy's initiative to reduce its climate footprint can be observed as a move in a positive direction, it should not distract from the fact that 'the main job [of the military] is to fight wars. That means breaking things and killing people...' (Burke, quoted in Goodell, 2015). In this regard, nature is being weaponized in two ways: first, the Navy is using a selective interpretation of futures made possible by climate change to project emerging threats which need military-style responses, even if those interventions are ostensibly humanitarian. In the GGF's first full-scale deployment, the carrier 
group was dispatched to the Mediterranean Sea at the same time as another carrier group ${ }^{2}$ that was in the process of 'setting records' for the number of bombs dropped on Syria (Eckstein 2016) - a conflict that is (problematically) considered by some as being driven in part by climate change-induced droughts (Kelley et al., 2015). This interpretation of threats then provides the justification for the second way nature is weaponized, which is increased support for the nascent domestic biofuels industry and a desire to break from existing fossil fuel infrastructures that allows for more military flexibility in response to these threats. This list of potential threats is growing, including deteriorating environmental conditions; these are contributing to humanitarian disasters and the disappearance of Arctic sea ice, leading to both new security challenges and commercial opportunities that require military protection.

Crucially, the Navy's 'green' transformation towards biofuels relies substantially on the private sector, as the Navy has neither experience nor remit to manufacture its own material, including (and especially) fuel. To accomplish its goal of sourcing half of its fuel from renewables by 2020, the Navy is directly financing purchase guarantees to bio-refineries and subsidizing infrastructure on a large scale (MacCormack, 2016). The US military has long been a significant actor in the US, and global, economy, not only because of its sheer purchasing power but also through its capacity to nurture new technologies, and even entire industries, from concept to large-scale deployment (Cypher, 1987). Industries supported by military purchasing, such as aluminium or microchips, have had profound impacts on local and global ecologies (Magaziner \& Reich, 1982; Mirsky, 2005). The Navy's move toward biofuels is framed as a 'win-win-win' as it looks to deliver positive environmental outcomes, while also furthering national security priorities and subsidizing a new US industry. These three aims are coincident with the analytical 
THIS IS A PRE-COPY EDITED DRAFT OF ACCEPTED ARTICLE IN POLITICAL GEOGRAPHY 2017

outlook of geopolitical ecology, encompassing geopolitics and political ecology, which in turn integrates political economy with environmental change.

In the next section, we describe the broad contours of the geopolitical ecology approach to highlight the US military as an environmental actor. We discuss previous political ecology approaches to military/environment relations (e.g. weaponizing nature) particularly in reference to militarized conservation - the focus of most literature. We demonstrate how the addition of critical geopolitics can enrich analyses of environmental change influenced by militaries or broader national security institutions or imperatives. Section three turns that geopolitical ecology lens towards the way the US military has developed climate change as a geostrategic discourse (Sparke, 2007) which understands global warming as a 'threat multiplier' that will increase the need for US military intervention across the globe. The empirical section that follows works through one of the ways in which the US military's geostrategic discourse is being mobilized to weaponize nature through the production of advanced biofuels. These new fuels are meant to both mitigate greenhouse gas emissions and allow operations to be adapted to changing climatic and geopolitical conditions. We discuss the political economic relations in which the US military is embedded to show how the military's understanding of climate change subsidizes new industries in the civilian realm. This section highlights the centrality of military procurement in the broader production of nature both through historical energy paradigms and in efforts to create new ones. The article concludes with a brief reflection on geopolitical ecology as an approach and ways forward in viewing the US military as a critical environmental actor.

\section{TOWARDS A GEOPOLITICAL ECOLOGY OF THE US MILITARY}


The US military has been (and continues to be) influential in the process of creating and constructing environmental policy agendas (Ross, 1996). From the enclosure of pristine environments for military bases to ecological restoration of former and active sites, it has always held privileged access to space and energy resources (Davis, 2007a, b). The military controls vast pools of money, knowledge, technology and has the political power to radically remake environments (Dudley, 2012). With this capacity, the military operates across multiple scales and far beyond domestic environments, extending to all its areas of operation, especially conflict zones. ${ }^{3}$ Furthermore, given the sheer force of its purchasing power, it is a central driver in global commerce of specific forms of energy (e.g. oil, uranium) and other natural resources (e.g. rare earth minerals). Last, wielding its immense political and economic influence, it is able to form and carry out self-defined agendas, sometimes independently of other facets of the state apparatus (Sheppard \& Tyner, 2016; Wainwright, 2016). The US military gains and maintains control of resources and environments with relative ease, and largely shapes US foreign policy imperatives to assure access to strategic spaces, to supply what historically has been a neverending need for fossil fuels (Nixon, 2011; Buxton \& Hayes, 2015). Yet, apart from a few exceptions, political ecologists have not closely engaged with the role of the US military in shaping socio-natural arrangements on broader scales (Wainwright, 2016), or with geopolitics in any meaningful way (Benjaminsen et al., 2017).

Interest in studying the military's relationship with the environment came to the fore in the early 1990s, with a focus on a post-cold war ideology coalescing around the doctrine of ‘environmental security’ and policy literature which took a deterministic neo-Malthusian lens of over-population leading to resource scarcity (Peluso \& Watts, 2001; Dalby, 2002; Benjaminsen et al., 2012). ${ }^{4}$ What made (and still makes) the discourse of 'securitization' so powerful was its 
framing of critical environmental problems and risks as central to the 'interests' of US national security $^{5}$, and so demanding military-style responses (Le Billon, 2008; Dunlap \& Fairhead, 2014). ${ }^{6}$ Environmental security therefore legitimized the use of military interventions to combat environmental problems in a new world order of sole US hegemony.

Recent work by political ecologists examines discourses around securitization and its relationship to resource conservation, demonstrating how these discourses are used by militaries as a justification for violence and as a way to advance their power and legitimacy (cf. Ybarra, 2012; 2016; Duffy 2016). The emergence of 'green militarization' studies, according to Lunstrum (2014), focuses on the increasing ramping-up of militaries and its particular meshing with wildlife conservation. She explains how conflicts around wildlife conservation in Africa and elsewhere are increasingly dealt with by 'paramilitary personnel, training, technologies and partnerships' and embedded within the violence of everyday conservation tactics $((2014$, p. 817 ; see also Büscher \& Ramutsindela, 2016; Duffy, 2016). She also shows how militaries re-invent themselves as environmental stewards in post-conflict zones as a way to gain and maintain legitimacy (Lunstrum, 2014). This military-style conservation includes forced evictions and displacement of rural inhabitants, sanctioned by environmental NGOs under wildlife protection and REDD+ de-carbonization schemes (Neumann, 1998; Kelly, 2011; Nel \& Hill, 2013; Cavanagh \& Himmelfarb, 2015). Cavanagh \& Benjaminsen (2014) note that the use of paramilitary forces for 'green territorialization' in Central and East Africa is a process supported through civil-society and donor funding for carbon offsetting, which has violently evicted local residents under 'green’ credentials (see also Neumann, 2004; Le Billon, 2008; Marijnen \& Verweijen, 2016). This 'green violence', Ybarra notes, becomes a way of legitimizing its claims over contested territory by deepening and extending state power (2016, pp. 497-498; see also 
THIS IS A PRE-COPY EDITED DRAFT OF ACCEPTED ARTICLE IN POLITICAL GEOGRAPHY 2017

Peluso \& Vandergeest, 2011; Duffy, 2016, p. 240) and is instrumental in justifying action against 'rebellious' groups and/or counter-insurgency operations (Ojeda, 2012; Verweijen \& Marijnen, 2016; Dunlap, 2017).

However, the relationship between militaries' use of nature to carry out violence is by no means new. Gregory (2016) shows that there is a long history of using nature as ' $\ldots$ a medium through which military and paramilitary violence is conducted' (see also Peluso \& Vandergeest, 2011). He goes on to say:

The spoils of war include the short-term bludgeoning of landscapes and the long-term toxicity of contamination (what Rob Nixon [2011] calls 'slow violence'), but it is also important to trace the bio-physical formations - the conditions, provided the term is understood in the most active of senses - that are centrally involved in the militarization of 'nature' (2016, p. 4).

Further, Dudley (2012) documents how the UK Ministry of Defence actively and forcefully protected nature 'through legislation, conservation policies, land management and responses to opposition...' (2012, p. 1). Dudley builds upon other geographers of military history who upend received notions that the military (and military sites) is only a force of nature's destruction, but rather an active agent of its protection (Davis, 2007a; Havlick, 2011). However, as Davis (2007a, p. 132) demonstrates, such militarized landscapes are not just protected, but are 'produced' through the violent erasing of both the social history of the landscape and the history of the military's use of it. This violent erasure illustrates the practical reality of why nature is actively protected by militaries; it is that soldiers need to learn how to kill in them. 
Yet beyond landscapes, specific aspects of nature can be (re-)appropriated by militaries as an 'agent of war'. Jake Kosek's insightful work on the 'ecological legacy' of empire examines the US Department of Homeland Security's use of the honeybee '... as a military technology and strategic resource for the battlefield' (2010, p. 651). Kosek situates his work in the cultural politics of nature and science and technology studies, drawing on the discursive and material praxis on the 'Global War on Terror' and provides a lucid example of the weaponization of nature through a post-9/11 lens of securitization. He shows the adoption of new technologies and surveillance through the use of bees (both biological and biomimetic) while providing a window into the future of 'militarized ecologies' - nature both produced for and used for warfare (2010, 670). ${ }^{7}$ Bees, according to Kosek, are the ultimate 'bio-monitors' employed to detect hazardous chemical and radioactive material and have become indispensable 'warfare detection teams' (2010, 659). Kosek's honeybee work helps show that war on and with nature has taken on new forms, but which also need new forms of enquiry which take into account the discursive and material interplay of large institutions as environmental actors (see also Duffy, 2014).

The reframing of the US military as an ecologically friendly actor and its self-styled relationship to the environment justifies the self-provisioning of infrastructure and material resources needed to carry out the protection of scarce nature, both home and abroad. The conditions under which the provisioning of the US military, and the US economy more broadly, takes place are now rapidly shifting in light of ecological and geopolitical changes. The US military is developing strategies to respond to these conditions, such as the adoption of biofuels in its GGF, as the broad contours of climate change impacts become more discernible and the US continues to reimagine its role in a rapidly changing and unpredictable geopolitical order as the world leader in 
THIS IS A PRE-COPY EDITED DRAFT OF ACCEPTED ARTICLE IN POLITICAL GEOGRAPHY 2017

securitizing responses to climate change. It is to those conditions under which US military climate strategy is playing out that we now turn.

\section{CLIMATE CHANGE AS A GEOSTRATEGIC DISCOURSE}

In constructing a discourse to support the development and deployment of renewable fuels, the Navy intermixes ideas about the dangers of climate change with the possibilities for new kinds of military intervention. The way the US military thinks about climate change was summarized by Secretary of Defense Chuck Hegel in the 2014 Quadrennial Defense Review - the United States' most visible high-level strategic planning document available to the public. Hegel (2014, p. 8) argues that:

As greenhouse gas emissions increase, sea levels are rising, average global temperatures are increasing, and severe weather patterns are accelerating. These changes ... will devastate homes, land, and infrastructure. Climate change may exacerbate water scarcity and lead to sharp increases in food costs. The pressures caused by climate change will influence resource competition while placing additional burdens on economies, societies, and governance institutions around the world. These effects are threat multipliers that will aggravate stressors abroad such as poverty, environmental degradation, political instability, and social tensions conditions that can enable terrorist activity and other forms of violence.

This summary of US military thinking on climate change reflects the degree to which top military planners worry about the destabilizing potential of climate change and, by extension, the ways in which they will need to prepare for those outcomes. The US military's geostrategic discourse on climate change links future 'turbulence' to global economies, environments and 
geopolitics (see Cooper, 2010). This turbulent world is defined by changes to formerly predictable, if not orderly, systems like global and regional food supplies, oil markets, raw commodities, and even the weather, which have become 'unstuck' from their historical baselines. ${ }^{8}$ For the military, this turbulence renders old predictors not only useless, but also potentially dangerous. The US Department of Defense (DoD) is the world's single largest consumer of refined hydrocarbons (Hegel, 2014). As such, it is particularly vulnerable to volatility in oil markets wherein price is largely decoupled from physical supply and demand (Labban, 2010), and where major oil producers are mired in interminable conflict or potentially hampered by environmental restrictions, and thus poses challenges to operations-as-usual. These challenges provide some of the impetus for the development of new energy strategies.

The first facet of the US Navy's climate-related geostrategic discourse is the recognition that dependence on existing hydrocarbon geographies has been, is, and will continue to be, extremely expensive and dangerous to continue to secure. Secretary Mabus (quoted in Cole, 2012) claimed that the rationale for subsidizing biofuels was primarily about extracting the Navy from extant energy geographies: 'If you look at the reasons we're doing it, we're not doing it to be faddish, we're not doing it to be green, we're not doing it for any other reason except it takes care of a military vulnerability that we have.' Elsewhere, another former Navy official elaborated on the dangers posed by reliance on conventional hydrocarbons:

We're forced to be interested in parts of the world because of our energy consumption ... Solving the energy problem solves a real security problem. You get to choose your points of engagement. It's like one of the things your grandmother told you. 'Don't go looking for trouble. If you find trouble, you have 
to deal with it - but don't go looking for it!' Well, when we go looking for oil, we're really looking for trouble (Farrell, in CNA, 2007, p. 28).

These two statements reflect a degree of recognition by the US Navy of its key function, which is to secure US commercial interests, especially access to cheap resources. US military intervention has been concentrated on securing access to energy resources over the last 30 years (Harvey, 2003), and no shortage of trouble has been found as a result, both in the proximate areas of intervention and as global blowback which continues to drive many facets of geopolitics worldwide. The protection of US access to cheap and plentiful hydrocarbons has played a major role in determining the geography of US military infrastructure, not only in the spaces of extraction but in the global oil distribution infrastructure of shipping lanes, pipelines, refineries, and the like (Mitchell, 2013). To this end, the US is not only building domestic biofuels refining capacity, but also collaborating with other countries, including Australia and Italy, to transform refuelling infrastructure and the geography of feedstock sourcing (Harrington, 2016).

The second discursive strand that animates military planning around climate change reflects the physical changes engendered by global warming and how military strategists expect those changes to destabilize countries, regions, and geopolitical relations. Economic and environmental turbulence is upsetting already unsettled geopolitics through shifting physical realities and the discourses of sovereignty on which they are constructed (Gerhardt et al., 2010; Steinberg, 2010). While climate change will have disruptive, unpredictable impacts globally, non-linear changes are experienced most dramatically in the Arctic, an area that, not coincidentally, the US Navy sees of increasing strategic importance (Hegel, 2014). The melting of Arctic sea ice is rendering the region nearly unrecognizable. Such physical changes accompany geopolitical shifts in which an emboldened Russia is availing itself of newly 
accessible resources and seeking to act as a guarantor of shipping lanes to suit its interests (Borgerson, 2008). The potential for conflict over resources and commercial hegemony is already in place; in some places on the Arctic seabed, seven different countries have made claims to underlying resources (Dodds, 2010). This increased attention to Arctic climate is emblematic of the US government's proclivity for seeing major challenges to its commercial hegemony as a military problem (Dalby, 2002, 2009). Chaturvedi \& Doyle (2015) note that moves by the US military to retain commercial hegemony and control of unfettered access to global energy resources are increasingly framed by environmental policymakers as issues of national security dovetailing neatly with the 'resource wars' version of climate change propagated in national security circles, as well as longer-running discourses on ‘environmental security’ (Le Billon 2008; Gilbert, 2012). As annual sea ice coverage continues to retreat, US military strategists increasingly understand this area as a potential new resource-rich 'battle space' (Titley, 2013). This move by the military requires overt US dominance in order to protect commercial interests and keep in check Russia's territorial ambitions, maintaining US hegemony over global supply chains (Gerhardt et al., 2010).

While the Navy's spatial reorientation is regularly discussed in relation to specific problemspaces, especially in the Arctic (e.g. Rosenberg, 2012), its climate change-informed strategy is strikingly global and turns on the conceptualization of climate change as a 'threat multiplier' in virtually any setting. Gilbert (2012) aptly demonstrates that this reduction of climate change to a threat multiplier - or that climate change is a national security threat that can be combatted by military means - dramatically narrows the possibilities of advocating for real climate security and our ability to ultimately break dependence on carbon-intensive forms of energy (see Urry, 2004). Gilbert shows that the catastrophism of climate scenario planning reflects the increasingly 
voluminous climate-conflict literature (Gleick, 2014; Kelley et al., 2015; O'Sullivan, 2015). ${ }^{9}$

This pessimistic, force-oriented outlook is also present much more broadly in the 'resource scarcity' literature. Neo-Malthusian influenced resource scarcity leading to interminable regional conflict over food, water or other resources is emblematic of how realist political science takes up climate change (Sutton et al., 2010; Scheffran et al., 2012; Hsiang \& Burke, 2014). The US military's adoption of this literature as part of its forward-looking planning in some ways makes its 'dystopian vision' of the future more, rather than less, likely. This is in part because of what we might think of as the military's 'use-it-or-lose-it' funding mentality: that is, as a bureaucratic institution competing for finite government appropriations, the military is unlikely to leave new weapons systems unused. New military kit, including biofuels infrastructure, that is justified by this conflict-rife vision of climate change is unlikely to be left idle.

Beyond its new green ambitions, the US Navy also likes to portray itself as a humanitarian organization in a hostile (both militarily and environmentally) world, as witnessed by its advertising campaign, launched near the same time as the beginning stages of the Great Green Fleet, featuring the slogan 'a global force for good' (US Department of the Navy, 2010). Indeed, many, if not most, recent US military interventions have been justified at least in part by an appeal to humanitarian ideals, from Haiti to Libya (Checcine et al, 2013; Robins-Early 2015) . With its catastrophic vision of future climates, this makes it easy to envision a never-ending series of humanitarian interventions in disaster areas or states that are perceived as failures because of climate-induced conflicts, in addition to the new battle spaces opened up by physical changes to the global ecology. The military perceives its coverage as already stretched thin by long-running campaigns in oil-rich places, but that it will increasingly be called on to provide disaster relief or protect civilians caught in the crossfire of resource wars (Hegel, 2014). 
In its thinking about future operating conditions, top military planners take climate change as a global problem with local manifestations in which they will probably be called up to intervene. While the 'global scope' of this outlook is not particularly new, there are a number of conditions that render this approach to, and understanding of, territory possible in new ways. Beyond the GGF, the US military have explored a range of technologies under the auspices of the 'everywhere war' (Gregory, 2011), in particular drones, more energy-efficient field gear, and the lily-pad network of bases around the world, which give them, and the Navy in particular, an increasingly credible claim to having global reach. These technologies have also rendered global space relatively flatter, as the US can, and regularly does, bend traditional notions of sovereignty in its willingness to conduct operations across the world (Kindervater, 2016). In this context, we appreciate that understanding climate change as a threat multiplier will serve as ample justification for increased US intervention because of the diversity of threats that already exist to be exacerbated. This is particularly the case once the discursive work of linking those threats to terrorism has been accomplished, as in the above quotation and the popular (and problematic) narrative that drought precipitated by climate change contributed to the Syrian civil war and attendant rise of Daesh (Kelley et al., 2015). However, even if we reject environmentally determinist explanations of conflict, we cannot discount the uptake of these theories by those in positions of power, as they remain productive of material interventions, of which the Navy's move towards biofuels is one.

The Navy's new techniques and technologies of alternative energy sourcing are being pursued with the ultimate aim of building capacity such that military operations can, at short notice, reach anywhere in the world. This once-futuristic vision of military theatre as smooth global space is being constructed in the face of new climate threats. This untethering operates in a number of 
THIS IS A PRE-COPY EDITED DRAFT OF ACCEPTED ARTICLE IN POLITICAL GEOGRAPHY 2017

ways, ranging from new logistical arrangements to bypass existing energy infrastructure to less stringent respect for sovereignty justified by the aims humanitarian intervention or counterterrorism. This interpretation of climate change as one of looming catastrophe aligns neatly with the vision of US forces as a sort of 'global first responder' to socio-natural disasters, wherein no disaster zone is too remote or far-flung for the delivery of humanitarian aid (Chaturvedi \& Doyle, 2015). Additionally, it is a challenge and opportunity for the Navy's role in maintaining orderly spaces of global commerce, evidenced by long-term deployments around the Horn of Africa to protect international shipping from pirates. This type of intervention is a striking example of the ways in which the military and environmental problems conjoin, as many Somali pirates began their actions as a way of protecting territorial waters from rapacious foreign megafishers and toxic dumping (Collins, 2016). ${ }^{10}$

\section{WEAPONIZED NATURE, MATERIALIZED}

The discursive arrangement produced by the US military, and its interlocutors, positions climate change as a challenging operational environment. This environment is marked by numerous small conflicts, new battle spaces, and changing energy spatialities where there is a premium on securing fuel in safe and cheaper ways. One of these ways in which the US Navy is trying to come to terms with such projections is through support for the creation of a new US domestic biofuels industry. Further, biofuels are only one component of the Navy's climate change strategy, which in turn is one of a suite of military programmes related to climate change. Energy efficiency, demand reduction measures, and infrastructure adapted to new physical challenges are all part of the Navy's climate toolkit. Below we focus on the political and economic conditions under which the Navy's biofuels programme is materializing and how they reflect key points of the discursive formation discussed above. The context in which the Navy is launching 
the Great Green Fleet is reminiscent of political resistance to the Navy's switch from coal to oil in the early 20th century. We then discuss the mechanisms by which the Navy is once again acting as a geopolitical ecological agent through its biofuels programme, and the role that the military plays in the larger political economy of US biofuels.

The GGF is an explicit reference to the Great White Fleet, Roosevelt's 1907 launch of 16 battleships on a 14-month circumnavigation of the globe. The armada marked the beginning of a symbolic and material break from the Navy's dependence on coal (and coal infrastructure) as the fleet transitioned to oil to power its vessels. Moreover, it confirmed Roosevelt's canny ability to push the US, albeit with significant political opposition at home, 'to project its power abroad' (Chambers \& Yativ, 2011, p. 61) thereby ushering in 'the American Century' (Yergin, 2011). As Whitty (2013) recounts:

Four squadrons of 16 battleships painted bright white and manned by 14,000 sailors and Marines on a 43,000-mile cruise around the world. It was the first ever armada of coal-powered steam battleships built entirely of steel - the product of years of government subsidies paying three times the market rate to develop a fledgling American steel industry. When Congress moved to blockade the fleet's around-the-world funding, Roosevelt snarled at them to 'try and get it back.' So the fleet sailed to 20 ports on six continents over 14 months, boldly going where no U.S. military had gone before and announcing the debut of the United States as a player on the World Ocean.

Similar to Roosevelt, the Obama administration and the Navy also picked up a host of interrelated discourses that remain highly contested in the power corridors of Washington. ${ }^{11}$ In both cases, the Navy plays a significant, if not decisive, role in nurturing critical industries. We 
can clearly see the continuing (geopolitical-ecological) impacts of Naval investment in steel production and oil infrastructure, and so it is not difficult to imagine the types of impacts a dramatically scaled-up biofuel industry might have on conventional hydrocarbon production. Significant Naval support for biofuels could have fundamental impacts on the US geography of energy, particularly in light of the ongoing disruption to conventional production by shale gas and the former Obama administration's apparently sincere (if technocratic) commitments to steer the US towards a lower carbon future. That sincerity was evident in the fact that the Navy stuck to its biofuels programme despite ongoing depression of oil prices., The future of the programme is uncertain under the Trump administration, as early pronouncements on the expansion of military spending are coupled with plans to cut other spending (especially climate-related).

More than ever, climate change is a fraught issue across different levels and agencies in the US government. This situation makes a coherent narrative on the importance of mitigating greenhouse gas emissions or adapting to a warming world largely impossible and imposes challenges on departments that ought to take climate change seriously. Given the magnitude of challenges posed by climate change, this ought to include most departments, including the Environmental Protection Agency, Housing and Urban Development, and Defense. However, in parts of the US, especially those driven by electoral politics, passing legislation to deal with greenhouse gas emissions, rising sea levels, or making international aid policy based on new environmental realities is effectively a non-starter. This is mainly because vast swathes of elected representatives (from both major parties), along with their constituents, simply do not support action on (or even believe in) climate change, following intense and costly lobbying and advertising campaigns by large emitters (Dunlap and McCright, 2010), and the capture of key state functions by fossil fuel industry alumni. However, as we have seen, other powerful blocs in 
the state, like the military and intelligence services, not only accept the material reality of climate change and worry about its impacts, but are actively implementing programmes for mitigation and adaptation. These programmes range from building dedicated smart-grids for military operations, for security and reduced energy usage, to building new, higher piers at naval installations to cope with rising seas (United States Navy, 2010).

For all its conviction that climate change represents a material threat to US military hegemony and the actions the DoD is taking to account for it, the disconnect between politicians and military planners remains. The military still maintains that climate change "may increase the frequency, scale, and complexity of future missions ... while at the same time undermining the capacity of our domestic installations to support training activities' (Hegel, 2014). Yet congressional Republicans continue to attempt to block most DoD programmes that specifically incorporate climate concerns into planning and procurement, indicating their enduring preference for supporting domestic fossil fuel industries, infrastructure, and associated modes of foreign policy and intervention over the uncertainty engendered by climate change and actions being taken to confront it. It is to these forward-looking actions we now turn, focusing specifically on the creation of the domestic biofuels market through military procurement justified by increased attention to the impacts of climate change. We do this in order to understand how one of the most powerful institutions in the history of the world is coming to terms with the new natural and political environments in which, informed by its climate outlook, it is now ensnared, despite political pressure to do the opposite.

Since Secretary Mabus announced the creation of the GGF in 2009, significant work has gone into the materialization of the bio-fuelled, more energy-efficient carrier group as part of larger 
DoD energy strategy. This work cuts across distinct but overlapping domains. On one hand, there is the sensitive discursive work of positioning the need for alternative fuels within the military's overarching vision of climate change as a threat multiplier, but in a way that operates within the political realities in which it now finds itself enmeshed, as discussed above. On the other, there is the actual political, regulatory, and business/procurement work to secure the resources necessary to facilitate the materialization of Mabus' vision, and then the materialization itself. The switch to advanced biofuels is not merely a matter of changing fuelpurchasing practices - the fuels themselves had to be designed and produced, along with the infrastructure for that production and their ultimate delivery. In short, the Navy is actively trying to build new industries and associated markets in 'green' fuels which the private sector has thus far failed to accomplish, and in doing so has reimagined itself as a purposeful geopolitical ecological actor. While the creation of a domestic, non-food 'third-generation' biofuels industry is the primary focus, we will also explore the broader sweep of climate-related technological and practical changes the Navy has instated in order to illustrate the diverse ways that the militarization of climate-change preparation has been instituted in practice.

When Secretary Mabus announced the GGF initiative the US third-generation biofuels industry was still in its gestational phase. The vast majority of biofuels refining capacity was (and still is) centred on ethanol production from food crops in the US Midwest and bio-refining techniques were promising but relatively unproven (United States Energy Information Administration, 2016). The Navy investigated a number of refining technologies and feedstock combinations, as well as companies to contract for fuel provision. The initial contract for demonstration fuels was awarded to Dynamic Fuels LLC - a joint venture between Syntroleum, a refining technology company in Tulsa, OK, and Tyson, the industrial agriculture giant headquartered in Fayetteville, 
THIS IS A PRE-COPY EDITED DRAFT OF ACCEPTED ARTICLE IN POLITICAL GEOGRAPHY 2017

AR. ${ }^{12}$ The refinery used Syntroleum's bio-refining technology to break down biological material - primarily used cooking oil and residual chicken fat from Tyson's industrial poultry operations in the region - into military-grade jet fuel and marine diesel, both of which have more exacting standards than their civilian counterparts (Harrington, 2016). While the bio-refinery built in Giesmar, LA, was tiny by global oil industry standards at a capacity of around 5,000 barrels per day, it represented a significant step towards the realization of the Navy's vision of future energy procurement, which nurtures specific technology and the third-generation advanced biofuels industry as a whole (MacDonald, 2011; Mick 2011).

Having proven the techniques and the suitability of the fuels through the GGF's initial cruise in 2012 using the fuels refined in Louisiana, the Navy issued grants worth \$210 million through the Defence Production Act $^{13}$ to three firms: Emerald Biofuels, Fulcrum Bioenergy and Red Rock Bio. The Navy provided these grants for the construction or retrofitting of three new facilities to supply fuel to the GGF, each using slightly different technologies and feedstocks (Lane, 2014). In addition to these three refineries, the fuel currently being used by the Navy (and supported through other federal funding mechanisms) is refined in South California by AltAir at a converted conventional refinery. What ultimately goes into the fuel tank of the GGF's ships and aircraft is $90 \%$ conventional, $10 \%$ biofuels, the feedstock for which is beef fat bought from Midwestern farmers and shipped to California for processing (MacCormack, 2016). The goal is to increase that proportion to $50 \%$ by 2020 (United States, 2010). At the launch of the GGF, the Louisiana refineries made fuels costing as much as \$15 per gallon, prompting a near-hysterical backlash in Congress, particularly on the part of hawkish, anti-climate science regulators like James Inhofe (Shachtman, 2011). These objections have been circumvented to some degree as the price has dropped precipitously over the last four years, and the current blend costs close to 
\$2 per gallon. In a sense, this demonstrates that Naval intervention in the biofuels markets is working - first, there is a third-generation biofuels industry, and moreover the fuel is being produced at scales allowing nominal prices to fall even if they fail to take into account subsidization costs through other funding mechanisms. It is also working in the sense that the refinery is producing fuels for commercial aviation. This demand is driven by a long-term purchase agreement between United Airlines and AltAir, demonstrating the immediate nonmilitary economic impact and influence on broader energy infrastructure. The Navy facilitates this scaling-up of industrial capacity through a willingness to pay far above market prices and outright grants and subsidies. It may be tempting to write this public-private partnership off as just another example of state-backed neoliberalization at work (Peck \& Tickell, 2002), but these practices easily predate any periodization of the neoliberal counter-revolution. The Navy's transition into a conscious agent of ecological modernization (Mol, 1996) is a variation on the military's long-standing role in demand-side economic policy, witnessed most dramatically in the mobilization for World War II but continuing to the present day. Just as the US military's environmental footprint is outsized, so is its economic influence.

Even though we argue that the Navy's move towards biofuels and other apparently green technologies should be taken seriously on their own terms, we need to maintain a critical eye on the environmental impacts of the military as a whole and the GGF itself. Geopolitical ecology can provide a framework this scrutiny. For all its talk about energy efficiency and the future of bio-fuelled operations, it may be that this just shifts energy usage elsewhere. For example, as Whitty (2013) writes regarding energy efficiency, 'Fuel-saving incentives are factored into promotions service wide. In 2011, these efforts saved $11 \%$ of fuel costs, awarding the Navy an additional 56,500 hours of "free" steaming time at sea' (n.p.). Just as we should be sceptical of 
any climate policy that primarily relies on energy efficiency for reducing fuel consumption while not undoing the underlying infrastructure of energy generation because of rebound effects (e.g. Khazzoom, 1980), we should be ready to evaluate a range of concerns around the 'greening of the military' as an explicitly ecological actor. Life-cycle greenhouse gas emissions from biofuels require critical appraisal, as do many of the Navy's other green initiatives. We must systemically consider the ramifications of the Navy as a conscious agent of ecological modernization in the service of maintaining and even expanding US global military hegemony while operating in the uncertain shadow of climate change. Even in the most green-positive interpretation of the GGF, its biofuels initiative is at best a pilot programme tinkering at the edges of the war machine, hoping to discover shortcuts to 'change so that nothing really has to change' (Swyngedouw, 2015). That is to say that even if the Navy, or the military as a whole, were to become carbon negative overnight, would its continued global operations, influenced as they are by a dystopian climate discourse, be economically, politically, ethically, or environmentally desirable?

\section{CONCLUSION}

This article puts forward a geopolitical ecology approach to address recent debates and developments around the US Navy's climate change discourse, its adoption of advanced biofuels, and the way it has supported the development of those fuels through interventions in domestic energy markets. This approach integrates the strengths of political ecology and geopolitics to see how large geopolitical institutions, such as the US Navy, emerge as key environmental actors and better understand how such institutions define, control and manage nature (Fairhead \& Leach, 1996; Peet \& Watts, 1996; Sullivan \& Stott, 2000; Peluso \& Watts, 2001). While recent work has begun to link political ecology and geopolitics (Sundberg, 2011), it still remains fertile ground for exploration and is particularly timely as increasingly global 
environmental challenges - from climate change to biodiversity conservation - are addressed by standing militaries and others with military-style responses (Lunstrum, 2016; Büscher 2016;

Dalby, 2016; Benjaminsen, et al., 2017). A geopolitical ecology frame of analysis is useful when thinking through some of the ways military force is utilized to protect or lay claim to nature, and historical contributions of militaries to environmental change. The US military in particular has been one of the most significant contributors to global environmental degradation at least since the launch of the Great White Fleet (Jorgenson et. al 2012; Jorgenson and Clark 2012). Understanding how such large institutions operate can help us better interpret a significant, but under-researched link between military operations and environmental change. It is therefore imperative to find ways to see the discursive and material consequences of military's conscious interventions in the environment and the broader application of geopolitical ecology to comprehend the role of large geopolitical institutions and environmental change.

This article represents a way of thinking about the US Navy's adoption of advanced biofuels and its biofueled fleet, alongside a host of energy-saving technologies, as part of its adaptation and mitigation strategies. We document the US military's framing of climate change and the nascent US biofuels industry as a way to achieve its changing interrelated and shifting geostrategic objectives. These objectives go beyond simple 'greenwashing', and are an attempt to decrease its reliance on conventional fossil fuels and reconfigure its energy sourcing, thereby reducing shortterm dependence on imported hydrocarbons. This is with an eye towards facilitating new renewable energy spatialities both for military operations and in the domestic energy consumption sphere that has historically necessitated US military interventions abroad while dramatically contributing to climate change. 
We have argued that the launch of the GGF represents a shift in the US Navy's relationship with nature mediated through a pessimistic geostrategic discourse around climate change. The reorientation of climate change as a serious issue in global geopolitics reflects the military's new conventional wisdom that future interventions will not resemble the traditional warfare of the 20th century. Instead, there will be a never-ending series of 'small wars' fought against non/quasi-states, like the ongoing, seemingly intractable hostilities in Syria, Iraq and Somalia (Boot, 2002), and humanitarian missions which can be tied back to climate change in some way (e.g. coastal flooding, prolonged drought). As we have noted, US military analysts are increasingly seeing these missions through the prism of climate change and more general resource scarcity $-\mathrm{a}$ 'threat multiplier' that will both foment new conflicts and exacerbate existing ones, as well as a strategic opportunity to reconfigure its spatial arrangements with regards to energy provision and the geopolitics those configurations co-constitute.

As noted above, it may be tempting to regard the Navy's interest in biofuels, and greenhouse gas mitigation more generally, as a public relations stunt akin to corporate greenwashing campaigns. However, if we take these initiatives lightly, we run the risk of underestimating the state's capacity to create new techno-environmental futures, a capacity it has demonstrated repeatedly. The Great White Fleet and the energetic socio-spatialities it engendered, with widespread and enduring implications, is just one example. One can also think of the Manhattan Project, endless interventions in oil-producing regions, and military support for the creation of the US federal highway system: all were instrumental in developing and commercializing technologies and energy-use paradigms that significantly contribute to the contemporary world economy and ecology (Huber, 2013; Moore, 2015). At this stage, it is not clear that this specific initiative will lead to widespread construction of new energy infrastructures or even a significant alteration in 
the operations of the Navy within broader US military strategy - many challenges to scaling up production remain, both political and economic. However, the case of the GGF is useful for understanding how one of the most powerful institutions in the world is coming to terms with rapid economic, geopolitical and environmental change by relying on techno-fixes to maintain the existing mono-polar global order through a combination of military strategy and public sector industrial planning and funding.

\section{REFERENCES}

Baechler, G. (1998). Why environmental transformation causes violence: A synthesis.

Environmental Change and Security Project Report, 4(1), 24-44.

Benjaminsen, T. A., Alinon, K., Buhaug, H., \& Buseth, J.T. (2012). Does climate change drive land-use conflicts in the Sahel? Journal of Peace Research, 49(1), 97-111.

Benjaminsen, T. A., Buhaug, H., McConnell, F., Sharp, J., \& Steinberg, P. E. (2017). Political

Geography and the environment. Political Geography, 56: A1-2.

Blaikie, P., \& Brookfield, H. (Eds.). (2015). Land degradation and society. Routledge.

Boot, M. (2002). The savage wars of peace: small wars and the rise of American power. New

York: Basic Books. 
THIS IS A PRE-COPY EDITED DRAFT OF ACCEPTED ARTICLE IN POLITICAL GEOGRAPHY 2017

Borgerson, S. G. (2008). Arctic meltdown: The economic and security implications of global warming. Foreign Affairs, 87(2), 63-77.

Büscher, B. (2016). 'Rhino poaching is out of control!' Violence, race and the politics of hysteria in online conservation. Environment and Planning A, 48(5), 979-998.

Büscher, B., \& Ramutsindela, M. (2016). Green violence: Rhino poaching and the war to save Southern Africa's peace parks. African Affairs, 115(458), 1-22.

Buxton, N., \& Hayes, B. (2015). The secure and the dispossessed. London: Pluto Press.

Cavanagh, C., \& Benjaminsen, T. A. (2014). Virtual nature, violent accumulation: the 'spectacular failure' of carbon offsetting at a Ugandan National Park. Geoforum, 56, 55-65.

Cavanagh, C. J., \& Himmelfarb, D. (2015). "Much in Blood and Money": Necropolitical ecology on the margins of the Uganda Protectorate. Antipode, 47(1), 55-73.

Chambers, A., \& Yativ, S. (2011). The Great Green Fleet: The U.S. Navy and fossil-fuel alternatives. Naval War College Review, 64(3), 61-77. 
THIS IS A PRE-COPY EDITED DRAFT OF ACCEPTED ARTICLE IN POLITICAL GEOGRAPHY 2017

Chaturvedi, S., \& Doyle, T. (2015). Climate terror: A critical geopolitics of climate change.

London: Palgrave McMillan.

Cecchine, G., Morgan, F., Wermuth, M., Jackson, T., Gereben Schaefer, A, Stafford, M. (2013).

The US Military Response to the 2010 Haiti Earthquake. Santa Monica, CA: Rand Corporation.

Clark, B. and Foster, J.B. (2009). Ecological Imperialism and the Global Metabolic Rift:

Unequal Exchange and the Guano/Nitrates Trade. International Journal of Comparative

Sociology. 50 (3-4): 311-334.

CNA Corporation. (2007). National security and the threat of climate change. Arlington, VA:

The CNA Corporation.

Cole, W. (2012). Biofuel helps power Navy’s war exercises. Honolulu Press Advertiser, 19th

July 2012.

Collins, V. (2016). Somalis fight back: Environmental degradation and the Somali pirate. In A.

Brisman, N. South, \& R. White (Eds.), Environmental Crime and Social Conflict: Contemporary

and Emerging Issues. (pp. 153-176). London: Routledge. 
THIS IS A PRE-COPY EDITED DRAFT OF ACCEPTED ARTICLE IN POLITICAL GEOGRAPHY 2017

Cooper, M. (2010). Turbulent worlds: financial markets and environmental crisis. Theory,

Culture \& Society, 27(2-3), 167-190.

Christophers, B. (2013). Banking across boundaries: Placing finance in capitalism. Chichester,

UK: Wiley-Blackwell.

Crosby, A. W. (1986). Ecological imperialism: The biological expansion of Europe, 900-1900.

Cambridge: Cambridge University Press.

Cypher, J.M. (1987). Military spending, technical change, and economic growth: A disguised

form of industrial policy? Journal of Economic Issues, 21(1): 33-59.

Dalby, S. (2002). Environmental security. Minneapolis, MN: University of Minnesota Press.

Dalby, S. (2009). Security and environmental change. London: Polity Press.

Dalby, S. (2014). Rethinking geopolitics: Climate security in the Anthropocene. Global Policy, $5(1), 1-9$.

Dalby, S. (2016). Framing the Anthropocene: The good, the bad and the ugly. The Anthropocene Review, 3(1), 33-51. 
THIS IS A PRE-COPY EDITED DRAFT OF ACCEPTED ARTICLE IN POLITICAL GEOGRAPHY 2017

Davis, J. S. (2007a). Military natures: Militarism and the environment. GeoJournal, 69(3), 131134.

Davis, J. S. (2007b). Scales of Eden: Conservation and pristine devastation on Bikini Atoll.

Environment and Planning D: Society and Space, 25(2), 213-235.

Dodds, K. (2010). On flag planting and finger pointing: The Law of the Sea, the Arctic and the political geographies of the outer continental shelf. Political Geography, 29(2), 63-73.

Dudley, M. (2012). An environmental history of the UK Defence Estate, 1945 to the present.

London: Bloomsbury Publishing.

Duffy, R. (2014). Waging a war to save biodiversity: the rise of militarized conservation.

International Affairs, 90(4), 819-834.

Duffy, R. (2016). War, by conservation. Geoforum, 69, 238-248.

Dunlap, R. E., \& McCright, A. M. (2010). Climate change denial: sources, actors and strategies.

In Level-Tracey, C. (ed), Routledge handbook of climate change and society. Abingdon, UK:

Routledge, 240-259. 
THIS IS A PRE-COPY EDITED DRAFT OF ACCEPTED ARTICLE IN POLITICAL GEOGRAPHY 2017

Dunlap, A. (2017). Counterinsurgency for wind energy: The Bíi Hioxo wind park in Juchitán,

Mexico. Journal of Peasant Studies, 1-23.

Dunlap, A., \& Fairhead, J. (2014). The militarisation and marketisation of nature: an alternative lens to 'climate-conflict'. Geopolitics, 19(4), 937-961.

Eckstein, M., (2016). Two CSGs In Mediterranean; Truman Attacking ISIS, Ike Demonstrating 'Great Green Fleet'. USNI News, 9 June 2016. Available at https://news.usni.org/2016/06/09/two-csgs-mediterranean. Last accessed 13 March 2017.

Fairhead, J., \& Leach, M. (1996). Misreading the African landscape: society and ecology in a forest-savanna mosaic. Cambridge: Cambridge University Press.

Gerhardt, H., Steinberg, P. E., Tasch, J., Fabiano, S. J., \& Shields, R. (2010). Contested sovereignty in a changing Arctic. Annals of the Association of American Geographers, 100(4), 992-1002.

Gilbert, E. (2012). The militarization of climate change. ACME: An International E-Journal for Critical Geographies, 11(1), 1-14.

Gleick, P. H. (2014). Water, drought, climate change, and conflict in Syria. Weather, Climate, and Society, 6(3), 331-340. 
THIS IS A PRE-COPY EDITED DRAFT OF ACCEPTED ARTICLE IN POLITICAL GEOGRAPHY 2017

Goodell, J. (2015). The Pentagon \& Climate Change: How deniers put national security at risk.

Rolling Stone, 12 February 2015 [online], available at

http://www.rollingstone.com/politics/news/the-pentagon-climate-change-how-climate-deniers-

put-national-security-at-risk-20150212. Last accessed 16 December 2016.

Gregory, D. (2011). The everywhere war. The Geographical Journal, 177(3), 238-250.

Gregory, D. (2016). The natures of war. Antipode, 48(1), 3-56.

Grove, R. H. (1996). Green imperialism: colonial expansion, tropical island Edens and the

origins of environmentalism, 1600-1860. Cambridge: Cambridge University Press.

Harrington, K. (2016). US Navy green fleet makes biofuels the new normal. American Institute

of Chemical Engineers, ChEnected [online], available at

http://www.aiche.org/chenected/2016/01/us-navy-green-fleet-makes-biofuels-new-normal. Last

accessed 26 January 2017.

Harvey, D. (2003) The new imperialism. Oxford: Oxford University Press.

Havlick, D. (2007). Logics of change for military-to-wildlife conversions in the United States.

GeoJournal, 69(3), 151-164. 
THIS IS A PRE-COPY EDITED DRAFT OF ACCEPTED ARTICLE IN POLITICAL GEOGRAPHY 2017

Havlick, D. G. (2011). Disarming nature: Converting military lands to wildlife refuges.

Geographical Review, 101(2), 183-200.

Hegel, C. 2014. Quadrennial Defense Review. Washington, DC: US Department of Defense.

Hess, K., \& Joyce, M. (2016). Secretary of the Navy launched Great Green Fleet. Currents,

Spring 2016, 16-21.

Homer-Dixon, T. F. (1999). Environment, scarcity, and conflict. Princeton, NJ: Princeton

University Press.

Hsiang, S. M., \& Burke, M. (2014). Climate, conflict, and social stability: What does the

evidence say? Climatic Change, 123(1), 39-55.

Huber, M. T. (2013). Lifeblood: Oil, freedom and the forces of capital. Minneapolis, MN:

University of Minnesota Press.

Jorgenson, A., Clark, B., \& Givens, J. (2012). The environmental impacts of militarization in comparative perspective: an overlooked relationship. Nature + Culture, 7(3): 314-337. 
THIS IS A PRE-COPY EDITED DRAFT OF ACCEPTED ARTICLE IN POLITICAL GEOGRAPHY 2017

Jorgenson, A. \& Clark B. (2016). The temporal stability and differences in the environmental impacts of militarism: the treadmill of destruction and consumption based carbon emissions.

Sustainability Science, 11(3): 505-514.

Kelley, C. P., Mohtadi, S., Cane, M. A., Seager, R., \& Kushnir, Y. (2015). Climate change in the Fertile Crescent and implications of the recent Syrian drought. Proceedings of the National Academy of Sciences, 112(11), 3241-3246.

Kelly, A. B. (2011). Conservation practice as primitive accumulation. Journal of Peasant Studies, 38(4), 683-701.

Khazzoom, D. (1980). Economic implications for mandated efficiency in standards for household appliances. The Energy Journal, 1(4), 21-40.

Kindervater, K. H. (2016). Drone strikes, ephemeral sovereignty, and changing conceptions of territory. Territory, Politics, Governance, 1-15 (online prepublication).

Koopman, S. (2016). Beware: Your Research May Be Weaponized. Annals of the American Association of Geographers, 106(3), 530-535. 
THIS IS A PRE-COPY EDITED DRAFT OF ACCEPTED ARTICLE IN POLITICAL GEOGRAPHY 2017

Kosek, J. (2010). Ecologies of empire: on the new uses of the honeybee. Cultural Anthropology, 25(4), 650-678.

Labban, M. (2010). Oil in parallax: Scarcity, markets, and the financialization of accumulation.

Geoforum, 41(4), 541-552.

Lane, J. (2013). USDA, US Navy unveil Farm to Fleet program: Navy “open for business” as shift to biofuels

blends begins. Biofuels Digest, 11 December 2013 [online], available at

http://www.biofuelsdigest.com/bdigest/2013/12/11/usda-us-navy-unveil-farm-to-fleet-program-navy-open-for-

business-as-shift-to-biofuels-blends-begins/. Last accessed 20 January 2017.

Lane, J. (2014). Inside the US Navy's new cost-competitive military biofuels program. Biofuels Digest, 21

September 2014 [online], available at http://www.biofuelsdigest.com/bdigest/2014/09/21/inside-the-us-navys-

new-cost-competitive-military-biofuels-program/. Last accessed 1 June 2017.

Le Billon, P. (2008). Diamond wars? Conflict diamonds and geographies of resource wars.

Annals of the Association of American Geographers, 98(2), 345-372.

Lenin, V. I. (1957). The national liberation movement in the East. Foreign Languages Publishing

House. 
THIS IS A PRE-COPY EDITED DRAFT OF ACCEPTED ARTICLE IN POLITICAL GEOGRAPHY 2017

Lunstrum, E. (2014). Green militarization: anti-poaching efforts and the spatial contours of

Kruger National Park. Annals of the Association of American Geographers, 104(4), 816-832.

Lunstrum, E. (2015). Conservation meets militarisation in Kruger National Park: Historical

encounters and complex legacies. Conservation and Society 13(4), 356-396.

MacCormack, J. (2016). US Navy's biofueled Great Green Fleet sets sail. Earthtechling, 9

February 2016 [online], available at http://earthtechling.com/2016/02/us-navys-biofuel-

powered-great-green-fleet-sets-sail/. Last accessed 26 January 2017.

MacDonald, P. (2011). Fuel from fats. enerG Magazine [online], available at

http://www.altenerg.com/back_issues/sepoct2011-story5.htm. Last accessed 26 January 2017.

Magaziner, I. C., \& Reich, R. B. (1983). Minding America's business: The decline and rise of the

American economy. New York: Vintage Books.

Marijnen, E., \& Verweijen, J. (2016). Selling green militarization: The discursive (re) production

of militarized conservation in the Virunga National Park, Democratic Republic of the Congo.

Geoforum, 75, 274-285. 
THIS IS A PRE-COPY EDITED DRAFT OF ACCEPTED ARTICLE IN POLITICAL GEOGRAPHY 2017

Mick, J. (2011). Military biofuel costs slashed thanks to massive Navy purchase, The Daily Tech.

[online], available at

http://www.dailytech.com/Military+Biofuel+Costs+Slashed+Thanks+to+Massive+Navy+Purcha

se/article23454.htm. Last accessed 26 January 2017.

Mirsky, R. (2005). Trekking through that Valley of Death: The Defense Production Act.

Innovation 3(3) [online], available at http://www.innovation-america.org/trekking-through-

valley-death-defense-production-act. Last accessed 18 October 2016.

Mitchell, T. (2003). Rule of experts: Egypt, techno-politics, modernity. Berkeley: University of

California Press.

Mitchell, T. (2013). Carbon democracy. London: Verso.

Mol, A. (1996). Ecological modernisation and institutional reflexivity: Environmental reform in the late modern age. Environmental Politics, 5(2), 302-323.

Moore, J. W. (2015). Capitalism in the Web of Life: Ecology and the accumulation of capital,

London, New York: Verso Books. 
THIS IS A PRE-COPY EDITED DRAFT OF ACCEPTED ARTICLE IN POLITICAL GEOGRAPHY 2017

Nel, A., \& Hill, D. (2013). Constructing walls of carbon - the complexities of community, carbon sequestration and protected areas in Uganda. Journal of Contemporary African Studies,

$31(3), 421-440$.

Neumann, R. P. (1998). Imposing wilderness: struggles over livelihood and nature preservation

in Africa. Berkeley: University of California Press.

Neumann, R. P. (2004). Moral and discursive geographies in the war for biodiversity in Africa.

Political Geography, 23(7), 813-837.

Nixon, R. (2011). Slow violence and the environmentalism of the poor. Cambridge: Harvard University Press.

Ojeda, D. (2012). Green pretexts: Ecotourism, neoliberal conservation and land grabbing in Tayrona National Natural Park, Colombia. Journal of Peasant Studies, 39(2), 357-375.

O’Sullivan, T. M. (2015). Environmental security is homeland security: Climate disruption as the ultimate disaster risk multiplier. Risk, Hazards \& Crisis in Public Policy, 6(2), 183-222.

Peck, J., \& Tickell, A. (2002). Neoliberalizing space. Antipode, 34(3), 380-404. 
THIS IS A PRE-COPY EDITED DRAFT OF ACCEPTED ARTICLE IN POLITICAL GEOGRAPHY 2017

Peet, R., \& Watts, M. (1996). Liberating ecology. In R. Peet, \& W. Watts (Eds.), Liberation

ecology. (pp. 3-42). London: Routledge.

Peluso, N. L., \& Watts, M. (2001). Violent environments. Cornell University Press.

Peluso, N. L., \& Vandergeest, P. (2011). Political ecologies of war and forests:

Counterinsurgencies and the making of national natures. Annals of the Association of American

Geographers, 101(3), 587-608.

Rosenberg, J. (2012). US Navy bracing for climate change. NASA Global Climate Change: Vital

Signs of the Planet, 22 March 2012 [online], available at http://climate.nasa.gov/news/699/us-

navy-bracing-for-climate-change/. Last accessed 26 January 2017.

Ross, A. (1996). Science wars. Durham: Duke University Press

Shachtman, N. (2011). Navy's big biofuel bet: 450,000 gallons at 4 times the price of oil. Wired,

5 December 2011 [online], available at https://www.wired.com/2011/12/navy-biofuels/. Last

accessed 26 January 2017.

Scheffran, J., Brzoska, M., Kominek, J., Link, P., \& Schilling, J. (2012). Climate change and

violent conflict. Science, 336, 869-871. 
THIS IS A PRE-COPY EDITED DRAFT OF ACCEPTED ARTICLE IN POLITICAL GEOGRAPHY 2017

Schiebinger, L. L. (2009). Plants and empire. Harvard University Press.

Sheppard, E., \& Tyner, J. (2016). Forum on geography and militarism: An introduction. Annals

of the American Association of Geographers, 106(3), 503-505.

Sparke, M. (2007). Geopolitical fears, geoeconomic hopes, and the responsibilities of geography.

Annals of the Association of American Geographers, 97(2), 338-349.

Steinberg, P. E. (2010). You are (not) here: On the ambiguity of flag planting and finger pointing in the Arctic. Political Geography, 29(2), 81-84.

Sullivan, S., \& Stott, T. (2000). Political ecology: science, myth and power. London: Arnold.

Sundberg, J. (2011). Diabolic caminos in the desert and cat fights on the rio: A posthumanist political ecology of boundary enforcement in the United States-Mexico borderlands. Annals of the Association of American Geographers, 101(2): 318-336.

Sutton, A. E., Dohn, J., Loyd, K., Tredennick, A., Bucini, G., Solórzano, A., Prihodko, L., \& Hanan, N. P. (2010). Does warming increase the risk of civil war in Africa?. Proceedings of the National Academy of Sciences, 107(25), E102-E102. 
THIS IS A PRE-COPY EDITED DRAFT OF ACCEPTED ARTICLE IN POLITICAL GEOGRAPHY 2017

Swyngedouw, E. (2015). Liquid power: Contested hydro-modernities in twentieth-century Spain.

Cambridge, MA: MIT Press.

Titley, D. (2013). Climate change series: Global warming a threat to national security. WBUR,

20 February 2013 [online], available at http://cognoscenti.legacy.wbur.org/2013/02/20/climate-

national-security-david-titley. Last accessed 21 January 2017.

United States Energy Information Administration. (2016). U.S. inputs to biodiesel production.

[Online], available at http://www.eia.gov/biofuels/biodiesel/production/table3.pdf. Last accessed

26 January 2017.

United States Navy (2010). US Navy climate change road map [online], available at

http://www.navy.mil/navydata/documents/CCR.pdf. Last accessed 26 January 2017.

United States Navy (2010). A Global Force for good [Television Commercial]. Available at

https://www.youtube.com/watch?v=q_HZtTOyihg. Last accessed 6 February 2017.

Urry, J. (2004). The ‘system’ of automobility. Theory, Culture \& Society, 21(4-5), 25-39. 
THIS IS A PRE-COPY EDITED DRAFT OF ACCEPTED ARTICLE IN POLITICAL GEOGRAPHY 2017

Verweijen, J., \& Marijnen, E. (2016). The counterinsurgency/conservation nexus: guerrilla

livelihoods and the dynamics of conflict and violence in the Virunga National Park, Democratic

Republic of the Congo. The Journal of Peasant Studies, 1-21.

Wainwright, J. D. (2016). The US military and human geography: Reflections on our

conjuncture. Annals of the American Association of Geographers, 106(3), 513-520.

Whitty, J. (2013). My heart-stopping ride aboard the Navy's Great Green Fleet. Mother Jones,

March/April [online], available at http://www.motherjones.com/environment/2013/02/navy-

climate-change-great-green-fleet. Last accessed 20 January 2017.

Ybarra, M. (2012). Taming the jungle, saving the Maya Forest: Sedimented counterinsurgency

practices in contemporary Guatemalan conservation. Journal of Peasant Studies, 39(2), 479-502.

Ybarra, M. (2016). 'Blind passes' and the production of green security through violence on the

Guatemalan border. Geoforum, 69, 194-206.

Yeargin, D. (2011). The prize: The epic quest for oil, money \& power. New York City, NY:

Simon and Schuster. 
${ }^{1}$ The degree to which any single event is attributable to climate change is difficult to ascertain, and all the more so when combined with complicated geopolitical and geo-historical relations that drive internal and international conflict.

${ }^{2}$ The GGF did not participate in combat operations at the time, though military officials highlighted the power of the 'optic' created by positioning multiple carrier groups in the Mediterranean at the same time (Eckstein, 2016).

${ }^{3}$ Not coincidentally, and many of which, according to leading environmentalists and military experts, overlap and are spatially congruent (Hanson et al., 2009, p. 578), with over $90 \%$ of the major armed conflicts between 1950 and 2000 occurring within countries containing biodiversity hotspots, and more than $80 \%$ taking place directly within hotspot areas.

${ }^{4}$ For examples, see Baechler, 1998; Homer-Dixon, 1999.

${ }^{5}$ National security in a contemporary sense: military operations to create and secure access to resources for national capitalists' interests date to the dawn of mercantilism, fostering colonialism and imperialism as we know it (Clark and Foster, 2009; Moore, 2015). The current realignment of US military strategy in light of climate change is intelligible through shifts in the dominant regime of accumulation in the same way that the alignment of commercial and military interests has always mirrored (or helped foment changes in political economy) the key characteristics of the capitalism of the time. In this case, the move towards flexibilization and everywhere-intervention is reflective of the degree to which the US economy is driven by the extraction of financial profits globally, relying on both extraction and production elsewhere (Christophers, 2013). 
${ }^{6}$ This has only intensified since $9 / 11$ as 'bio-securitization' has risen to the level of being a national security risk. Threats arising from fears of bioterrorism have been picked up by the US Department of Homeland Security and other wings of the US military under the banner of the 'Global War on Terror' as a way to secure and contain threats before they materialize (Kosek, 2010).

${ }^{7}$ Kosek also brings into conversation other relevant works of weaponized nature through the lens of geopolitical ecology, such as Tim Mitchell (2002) on the role of the mosquito in transforming the colonial legacy in Egypt, 'green' ecologies of empire (Crosby, 1986; Grove, 1996), and gendered and racialized scientific botany (Schiebinger, 2009).

${ }^{8}$ As seen in global food and oil commodity spikes in 2011.

${ }^{9}$ Most recently popularized by the notion that climate change is to blame for the Syrian civil war.

${ }^{10}$ Our thanks to an anonymous reviewer for bringing toxic dumping as a factor in the growth of Somali piracy to our attention.

${ }^{11}$ Given the recent military-heavy appointments of President Trump to top cabinet posts, such as Defense, Homeland Security and National Security Advisor, and his recent climate-denial rhetoric, we expect a continuation of this discordant and contested debate to continue. We do feel, however, that given the massive investment already and length of time it takes to change procurement, we do not foresee the US Navy's strategy changing radically any time soon.

12 This relationship between the waste products of the US petroleum-based agro-food system and the nascent biofuels industry deserves much closer empirical investigation and theorization, particularly as it is being situated within the military-industrial complex. 
13 The Defence Production Act was introduced in 1950 to support the development of industries critical to maintaining US industrial and technological supremacy in the Cold War. It has been a significant funding channel for the development of defense-priority industries like domestic mining of critical raw materials, and later supported the semi-conductor industry's development (Mirsky, 2005). 